\title{
The efficiency of sputum cell counts in cystic fibrosis
}

\author{
Lata Jayaram MD, N Renee Labiris MSc PhD, Ann Efthimiadis MLT, Helen Vlachos-Mayer MD, \\ Frederick E Hargreave MD, Andreas P Freitag MD
}

L Jayaram, NR Labiris, A Efthimiadis, H Vlachos-Mayer, FE Hargreave, AP Freitag. The efficiency of sputum cell counts in cystic fibrosis. Can Respir J 2007;14(2):99-103.

BACKGROUND: Technical factors relating to processing viscid sputum in cystic fibrosis (CF) and their influence on the reproducibility and validity of cell counts need to be evaluated. In addition, the methods need to be standardized so that they can be applied clinically and in research.

OBJECTIVE: To examine the efficiency, reliability and validity of processing small volumes of spontaneously expectorated sputum from subjects with CF.

METHODS: Sputum was collected from adults with CF $(n=35)$ and compared with sputum from adults with infective bronchitis or bronchiectasis (IB/B) $(n=16)$, or with asthma or chronic obstructive pulmonary disease (AS/COPD) $(n=25)$. Selected sputum (100 mg to $200 \mathrm{mg}$ ) was processed with dithiothreitol $(0.1 \%)$ and filtered. Total cell count (TCC) and viability were obtained in a counting chamber and cytospins were prepared and stained with Wright's for a differential cell count. Sputum and filter remnant were processed for TCC, viability and differential cell count, and the efficiency was determined by comparing the mean loss in cell yield to the filter. Two different portions from the same sputum sample were processed for cell counts to determine reproducibility. Results were compared with those from IB/B and AS/COPD groups.

RESULTS: Efficiency of cell dispersal was excellent and similar to that in AS/COPD and IB/B groups. Reproducibility of cell counts from two portions of a sputum sample was high $(R \geq 0.80)$. CF sputum demonstrated a raised TCC and neutrophilia similar to IB/B but significantly higher than AS/COPD.

CONCLUSION: The selection method of evaluating cell counts in viscid CF sputum is efficient, reproducible and valid.

Key Words: Airway inflammation; Cystic fibrosis; Sputum cell counts

Sputum cell counts are now used in four Canadian respiratory Scentres in clinical practice and worldwide in research to investigate the presence, type and severity of airway inflammation in bronchitis, asthma and chronic obstructive pulmonary disease (COPD), and to monitor the short- and long-term effects of treatment $(1,2)$. The measurements may also be useful for similar purposes in cystic fibrosis (CF), a disease associated with persistent neutrophilic airway inflammation.

Technical factors involved in the processing of spontaneous and induced sputum from subjects with asthma and their influence on the reproducibility and validity of cell counts have been extensively evaluated and standardized (3). The methods used in Canada include selection of a small volume or weight

\section{La mucoviscidose et l'efficacité des méthodes de numération cellulaire dans les expectorations}

CONTEXTE : Des facteurs techniques liés au traitement des expectorations épaisses, produites dans la mucoviscidose (MV) exigent une évaluation de leur influence sur la reproductibilité et la validité de la numération cellulaire. De plus, la normalisation des méthodes s'impose pour permettre leur application en pratique clinique et dans la recherche.

BUT : L'étude avait pour but d'évaluer l'efficacité, la fiabilité et la validité des techniques de traitement de petits volumes d'expectorations produites spontanément chez des personnes atteintes de MV.

MÉTHODE : Nous avons procédé à une collecte d'expectorations chez des adultes atteints de MV ( $\mathrm{n}=35)$ et nous les avons comparées aux expectorations obtenues chez des adultes souffrant d'une bronchite infectieuse ou de bronchiectasie (BI/B) ( $\mathrm{n}=16)$ ou encore d'asthme ou d'une bronchopneumopathie chronique obstructive (A/BPCO) (n=25). Une partie (100 à 200 mg) des expectorations a été traitée au dithiothréitol à $0,1 \%$, puis filtrée. Il y a eu numération cellulaire (NC) totale et mesure de la viabilité dans un récipient de numération, et des lames de centrifugation ont été préparées et colorées à la solution de Wright pour permettre une numération cellulaire différentielle. Le reste des expectorations et du filtre a été traité en vue d'une NC totale, d'une mesure de la viabilité et d'une NC différentielle, et l'efficacité a été déterminée par la comparaison de la perte moyenne de cellules dans le produit recueilli par rapport au filtre. La reproductibilité a été déterminée à partir du traitement de deux parties différentes d'un même prélèvement d'expectorations en vue d'une numération cellulaire. Les résultats ont été comparés à ceux enregistrés dans les groupes $\mathrm{BI} / \mathrm{B}$ et $\mathrm{A} / \mathrm{BPCO}$.

RÉSULTATS : L'efficacité de la dispersion cellulaire était excellente et comparable à celle obtenue dans les groupes $\mathrm{A} / \mathrm{BPCO}$ et $\mathrm{BI} / \mathrm{B}$. La reproductibilité de la numération cellulaire à partir de deux parties différentes d'un même prélèvement s'est montrée très bonne $(R \geq 0,80)$. Les expectorations produites dans la MV ont révélé une augmentation de la NC totale et de la neutrophilie comparable à celle observée dans le groupe $\mathrm{BI} / \mathrm{B}$ mais passablement plus forte que celle notée dans le groupe A/BPCO.

CONCLUSION : La méthode de sélection pour procéder à l'évaluation de la numération cellulaire dans des expectorations épaisses, liées à la mucoviscidose est efficace, reproductible et valide.

of sputum, treatment with four times the amount of dithiothreitol (DTT) to break up the mucus and disperse the cells, filtration, and the measurements of cell viability and total and differential cell counts (3). In CF, the volume of sputum produced, presence of DNA and F-actin embedded in the glycoprotein network and its viscoelastic properties may cause difficulty when processing CF sputum $(4,5)$ and the efficiency of the selection method using DTT has been questioned. One study (6) found incomplete dispersal and falsely lowered cell counts, while an enzyme mixture produced reliable counts. We therefore re-examined the efficiency, reproducibility and validity of processing a small portion ( $100 \mathrm{mg}$ to $200 \mathrm{mg}$ ) of selected spontaneous expectorated sputum treated with DTT from

Airways Research Group, Firestone Institute for Respiratory Health at St Joseph's Healthcare, Cystic Fibrosis Clinic at Hamilton Health Sciences, and Department of Medicine, McMaster University, Hamilton, Ontario

Correspondence: Dr Renee Labiris, McMaster University, 1200 Main Street West, HSC 1V11, Hamilton, Ontario L8N 325.

Telephone 905-521-2100 ext 75657,fax 905-546-1125, e-mail labir@mcmaster.ca 
subjects with CF and compared these data with those from sputum obtained from subjects with stable asthma or COPD (AS/COPD) and from others with infective bronchitis or bronchiectasis (IB/B) in whom the method has previously been validated (1). We also compared the reliability of cell counts from serial specimens over $1 \mathrm{~h}$.

\section{METHODS}

\section{Subjects}

Thirty-five subjects with CF, 25 with AS/COPD and 16 with IB/B were recruited from the adult CF clinic at McMaster University (Hamilton, Ontario) and from the Firestone Institute for Respiratory Health at St Joseph's Healthcare (Hamilton, Ontario) (Table 1). CF was defined by chronic respiratory symptoms, pancreatic insufficiency, a positive sweat chloride test greater than $60 \mathrm{meq} / \mathrm{L}$ and DNA analysis. The subjects were clinically stable and infected with Pseudomonas aeruginosa. Asthma was defined by symptoms of episodic wheeze, chest tightness and/or dyspnea, and by a $12 \%$ or greater reversibility in forced expiratory volume in $1 \mathrm{~s}$ $\left(\mathrm{FEV}_{1}\right)$ after $200 \mu \mathrm{g}$ of inhaled salbutamol. COPD was defined by a $\mathrm{FEV}_{1} /$ slow vital capacity ratio of $70 \%$ or less after bronchodilation. Although asthma and COPD are two different diseases, it was decided to combine the subjects because they often coexist and the method of sputum examination has been shown to be valid and reproducible in them. Infective bronchitis was defined by a current history of lower respiratory tract symptoms (without clinical evidence of pneumonia), associated with purulent sputum and positive sputum bacterial culture. Bronchiectasis was diagnosed from daily symptoms of productive cough and a characteristic high-resolution computed tomography scan of the chest; the sputum was chronically infected with either $P$ aeruginosa or Hemophilus influenzae. AS/COPD and IB/B subjects were clinically stable at the time of their visit and had no evidence of an upper or lower respiratory tract infection. The study was approved by McMaster University and the St Joseph's Healthcare Research Ethics Board and all subjects gave written informed consent.

\section{Study design}

CF subjects underwent a series of three prospective, cross-sectional trials, with studies 1 and 2 including control groups (AS/COPD and $I B / B$ ). All studies consisted of a single visit during which patient characteristics were documented and spirometry was performed. A spontaneous sputum sample was collected from subjects with $\mathrm{CF}$ and $\mathrm{IB} / \mathrm{B}$, and induced samples were collected from subjects with AS/COPD. In the first trial, spontaneous sputum was obtained from 10 subjects with CF. The efficiency of cell dispersion was compared with sputum obtained from 10 subjects with IB/B and 10 subjects with AS/COPD. In the second trial, the reproducibility of cell counts were compared between two selected portions of the same sputum sample in 15 subjects with CF. The validity was determined by comparing the measurements in $\mathrm{CF}$ with $15 \mathrm{AS} / \mathrm{COPD}$ and eight IB/B subjects. In the third trial, four serial spontaneous samples were collected at 15 min intervals over $1 \mathrm{~h}$ in 10 subjects with CF to assess changes in sputum cell counts over time.

\section{Sputum processing and cytology}

Spirometry was performed using a Koko spirometer to American Thoracic Society specifications (7) and reference values from Crapo et al (8). The baseline $\mathrm{FEV}_{1}$ was calculated as the best of three reproducible values (within a maximum change of $5 \%$ ). Sputum was collected and examined by the selected method described by Pizzichini et al (9). Subjects were instructed to rinse their mouth with water and swallow, and blow their nose to avoid contamination of the specimen with saliva and postnasal drip. Sputum was then expectorated into a sterile container and processed within $2 \mathrm{~h}$.

The following processing procedure was applied to sputa from the $\mathrm{CF}, \mathrm{IB} / \mathrm{B}$ and $\mathrm{AS} / \mathrm{COPD}$ groups. The specimen was poured into a tissue culture dish and the macroscopic appearance was recorded. Using inverted microscopy, a portion of sputum between $100 \mathrm{mg}$ to $200 \mathrm{mg}$ with little or no squamous epithelial cell contamination was selected and placed in a $15 \mathrm{~mL}$ conical tube. It was then treated with four times the volume of $0.1 \%$ DTT (Sputalysin 10\%, Calbiochcem Corp, USA) freshly diluted 1:10 with distilled water, vortexed for $15 \mathrm{~s}$ and rocked for $15 \mathrm{~min}$ to break up the mucus and disperse cells. A further four volumes of phosphate buffered saline was added to the suspension and filtered through $53 \mu \mathrm{m}$ nylon mesh (Morgans Canada). The total cell count and viability were obtained simultaneously in a modified Neubauer chamber. Cytospins were prepared, stained with Wright's for a 400 nonsquamous differential cell count. Sputum from AS/COPD and IB/B subjects was processed in the same way (9).

In the first study, the effectiveness of cell dispersion was determined by comparing the amount of sputum filtered through the filter (defined as the filtrate) with that left on the filter (defined as the remnant). Effective cell dispersion was defined, a priori, as $10 \%$ or less loss in total cell yield to the filter when compared with the filtrate (10). Both the filtrate and remnant were processed for cell counts. The differential cell counts recovered in the filtrate was compared with the remnant to ensure that the filter was not trapping certain cells selectively. Efficient processing was defined as the presence of effective cell dispersion without selective cell loss to the filter.

In the second study to determine reproducibility of measurements from two portions within the same sample, similar weights of sputum were processed and total and differential cell counts were compared. In the third trial, four sputum samples of similar weights were examined. Sputum measurements were made blind to clinical details.

\section{Statistical analysis}

Normally distributed data were expressed using arithmetic mean and standard deviations and non-normal distributed data as median and interquartile ranges. Differences between the filtrate and filter remnant were determined using a paired $t$ test for normally distributed and log-transformed data where possible, or the Wilcoxon Rank test for data not normally distributed. Reproducibility of sputum cell counts between the two portions from the same sputum sample was expressed by the intraclass correlation coefficient (R) and a $R \geq 0.8$ was considered acceptable. Differences between disease groups (validity) were determined using repeated measures ANOVA for normally distributed or log-transformed data. Posthoc analysis was performed by the Sidak test. Differences in cell counts and fluid phase measurements among serial sputum samples were determined using repeated measures ANOVA. Significance was accepted at a $\mathrm{P} \leq 0.05$. Statistical analysis was performed with SPSS Windows Version 10.0 (SPSS Inc, USA).

\section{RESULTS}

Subjects with CF were significantly younger than those with AS/COPD and IB/B (Table 1). All three groups had a similar $\mathrm{FEV}_{1}$ per cent predicted (Table 1). The mean loss in total cell yield to the filter with CF sputum was 5.3\% (SD 4.7) 
TABLE 1

Patient characteristics

\begin{tabular}{|c|c|c|c|}
\hline Characteristic & $\begin{array}{c}\text { CF } \\
(n=35)\end{array}$ & $\begin{array}{c}\text { AS/COPD } \\
(n=25)\end{array}$ & $\begin{array}{c}\text { IB/B } \\
(n=16)\end{array}$ \\
\hline Age $^{*}$, years & $20(6)$ & $66(7)$ & $51(11)$ \\
\hline Sex, male & 11 & 8 & 6 \\
\hline Smoking, current/ex-smoker & $0 / 0$ & $2 / 10$ & $0 / 5$ \\
\hline Atopy, $\mathrm{n}$ & 2 & 16 & 0 \\
\hline Inhaled steroids* ${ }^{\star}, \mathrm{n}$ & 10 & 18 & 12 \\
\hline Pulmozyme $^{\star}, \mathrm{n}$ & 6 & 0 & 0 \\
\hline $\mathrm{FEV}_{1}$ baseline, $\%$ predicted & $53(26)$ & $55(24)$ & $54(16)$ \\
\hline $\mathrm{FEV}_{1} N \mathrm{NC}^{* *}, \%$ & $69(15)$ & $57(19)$ & $54(16)$ \\
\hline FEV $_{1}$ reversibility* $\%$ & $3(5)$ & $14(11)$ & $11(5)$ \\
\hline
\end{tabular}

Data are presented as mean (SD) unless otherwise specified. ${ }^{*} P<0.001$; ${ }^{\star \star} P<0.05$. AS/COPD Asthma or chronic obstructive pulmonary disease; Atopy One or more positive allergy skin prick tests; CF Cystic fibrosis; IB/B Infective bronchitis or bronchiectasis; FEV 1 Forced expiratory volume in $1 \mathrm{~s}$; VC Vital capacity

TABLE 2

Efficiency of cell dispersion in cystic fibrosis sputum measured by cell counts in filtrate versus filter remnant

\begin{tabular}{lccc}
\hline & Filtrate & Filter remnant & $\mathbf{P}$ \\
\hline Total cell count, 10\%/g & $28.3(27.9)$ & $1.5(1.3)$ & 0.003 \\
Viability, \% & $70.0(31.0)$ & $70.0(52.0)$ & 0.91 \\
Neutrophils, \% & $97.8(2.3)$ & $99.6(0.7)$ & 0.90 \\
Eosinophils, \% & $0.3(0.8)$ & $0.0(0.2)$ & 0.09 \\
Lymphocytes, \% & $0.0(0.0)$ & $0.0(0.0)$ & 0.29 \\
Macrophages, \% & $1.0(2.1)$ & $0.3(0.5)$ & 0.32 \\
\hline
\end{tabular}

Results are expressed as median (interquartile range)

with no significant selective loss of cells in the filter (Table 2). This finding was similar to the efficiency in AS/COPD and $\mathrm{IB} / \mathrm{B}$, where the mean loss in total cell yield was $7.5 \%$ (SD 17.0) and $8.6 \%$ (SD 9.0), $\mathrm{P}=0.37$.

When two selected portions from the same CF sputum sample were compared, the total and differential cell counts were highly reproducible (Table 3 ). The results obtained from four sputum specimens obtained over $1 \mathrm{~h}$ were not significantly different (Table 4).

Sputum from CF subjects, in comparison with AS/COPD subjects, had a higher median total cell count $\left(47.6 \times 10^{6}\right.$ cells $/ \mathrm{mL}$ sputum versus $3.4 \times 10^{6}$ cells $\left./ \mathrm{mL}, \mathrm{P}=0.0002\right)$, a higher percentage of neutrophils (median percent, 96.3 versus $54.7, \mathrm{P}=0.001$ ), and lower percentage of eosinophils (median 0.3 versus 5.8, $\mathrm{P}=0.0005$ ) and macrophages (median 3.3 versus 39.5, $\mathrm{P}<0.0001$ ) (Figure 1, Table 3). Sputum from CF and IB/B subjects had similar total and differential cell counts (Figure 1, Table 3). IB/B sputum had a median total count of $61.1 \times 10^{6}$ cells $/ \mathrm{mL}$, of which $92.3 \%$ were neutrophils, $0.25 \%$ eosinophils and $7.2 \%$ macrophages.

Six subjects had therapy with recombinant human deoxyribonuclease, a proteolytic agent, which may theoretically affect sputum cell counts. Analysis of the data with and without these subjects did not demonstrate a significant difference (data not shown).

\section{DISCUSSION}

The results of the present study identify the efficiency of cell dispersal using a small quantity of selected CF sputum with $0.1 \%$ DTT, and the reproducibility of sputum cell counts.
TABLE 3

Reproducibility of sputum inflammatory indices in two selected portions ( $A$ and $B$ ) from the same sample

\begin{tabular}{lcccc}
\hline Cystic fibrosis & Portion A & Portion B & $\mathbf{R}$ & $\mathbf{P}$ \\
\hline Total cell count,106/g & $47.6(39.1)$ & $36.7(45.0)$ & 0.96 & 0.30 \\
Viability, \% & $80.0(21.0)$ & $81.0(20.0)$ & 0.97 & 0.65 \\
Neutrophils, \% & $96.3(3.7)$ & $96.5(5.2)$ & 0.80 & 0.96 \\
Eosinophils, \% & $0.3(0.5)$ & $0.3(0.8)$ & 0.87 & 0.80 \\
Lymphocytes, \% & $0.0(0.0)$ & $0.0(0.0)$ & 0.96 & 1.00 \\
Macrophages, \% & $3.3(3.6)$ & $3.2(3.2)$ & 0.73 & 0.60 \\
Asthma/chronic obstructive pulmonary disease & & \\
\hline Total cell count,106/g & $3.4(5.0)$ & $2.3(7.5)$ & 0.97 & 0.87 \\
Viability, \% & $61.0(49.0)$ & $60.0(40.0)$ & 0.97 & 0.52 \\
Neutrophils, \% & $54.7(32.0)$ & $46.2(32.5)$ & 0.97 & 0.56 \\
Eosinophils, \% & $5.8(14.0)$ & $6.8(11.1)$ & 0.96 & 0.55 \\
Lymphocytes, \% & $0.0(0.5)$ & $0.3(0.8)$ & 0.97 & 0.32 \\
Macrophages, \% & $39.5(31.0)$ & $42.0(22.0)$ & 0.77 & 0.35 \\
Infective bronchitis/bronchiectasis & & & \\
\hline Total cell count, 10\%/g & $61.2(78.8)$ & $53.1(89.2)$ & 0.99 & 0.13 \\
Viability, \% & $87.0(9.5)$ & $88.5(3.5)$ & 0.98 & 0.27 \\
Neutrophils, \% & $92.4(7.0)$ & $92.6(5.4)$ & 0.95 & 0.30 \\
Eosinophils, \% & $0.3(0.6)$ & $0.4(2.6)$ & 0.94 & 0.10 \\
Lymphocytes, \% & $0.0(0.2)$ & $0.0(0.2)$ & 0.91 & 1.00 \\
\hline Data are express & & & & \\
\hline
\end{tabular}

Data are expressed as median (interquartile range); $R$ Intraclass correlation coefficient

TABLE 4

Reproducibility of sputum inflammatory indices. Cystic fibrosis subjects produced four sputum samples over a $1 \mathrm{~h}$ period

\begin{tabular}{lccccc}
\hline & \multicolumn{5}{c}{ Sample number } \\
\cline { 2 - 5 } & $\mathbf{1}$ & $\mathbf{2}$ & $\mathbf{3}$ & $\mathbf{4}$ & $\mathbf{P}$ \\
\hline Total cell count, $10^{6} / \mathrm{g}$ & $12.9(29.5)$ & $23.0(18.0)$ & $16.7(12.1)$ & $21.3(26.9)$ & 0.87 \\
Viability, \% & $77(36)$ & $81(17)$ & $78(11)$ & $67(22)$ & 0.15 \\
Neutrophils, \% & $95.0(3.1)$ & $96.3(5.6)$ & $95.2(3.5)$ & $95.2(6.4)$ & 0.82 \\
Eosinophils, \% & $0.5(0.5)$ & $0.7(0.8)$ & $0.5(0.8)$ & $0.3(0.8)$ & 0.71 \\
Macrophages, \% & $4.7(4.2)$ & $2.4(5.5)$ & $4.0(3.1)$ & $4.5(5.5)$ & 0.31 \\
\hline
\end{tabular}

Results are expressed as median (interquartile range)

The results differ from those of Cai et al (6) who observed that sputum processing methods using DTT may not yield optimum cell counts in CF sputum. They found a significant loss of total cells and neutrophils attributable to incomplete dispersion of the sample. We applied a similar method of sputum processing using a comparable volume of DTT and phosphate buffered saline relative to sputum weight. However, we processed a smaller quantity of sputum, $100 \mathrm{mg}$ to $200 \mathrm{mg}$ versus $300 \mathrm{mg}$ used by Cai et al. This resulted in an efficient cell dispersion and filtration. The efficiency of our method was similar to that observed in subjects with AS/COPD and IB/B in the present study and to that reported in the literature in subjects with COPD, asthma and bronchitis $(10,11)$. In another study using the selection method but larger volumes (more than $1.5 \mathrm{~mL}$ ) from clinically stable CF subjects (12), markedly lower total and differential cell counts were reported than in the present study and that of Cai et al (6), again raising the possibility of incomplete cell dispersion due to the quantity of 


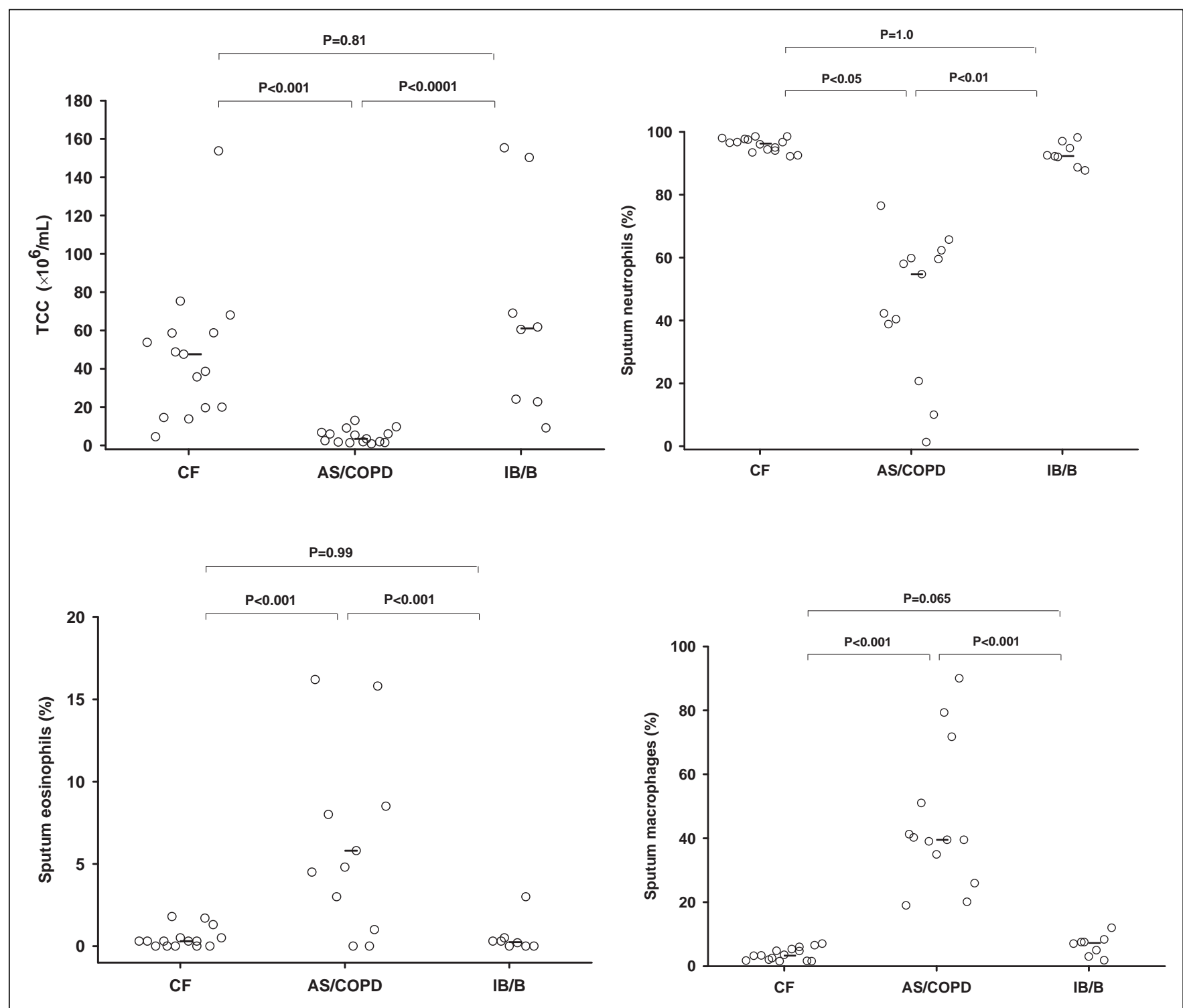

Figure 1) Sputum total and differential cell counts in subjects with cystic fibrosis (CF), asthma and chronic obstructive pulmonary disease (AS/COPD), and infective bronchitis and bronchiectasis (IB/B). Horizontal bars represent the median value. TCC Total cell count

sputum being processed. It has been suggested that DTT may not be an effective dispersal agent in CF because the sputum contains extracellular DNA and F-actin, in addition to mucus glycoproteins. However, a recent study by Nielson et al (13) investigating the viscoelastic properties of CF sputum reported that DTT treatment reduced the elasticity of the sputum by more than $90 \%$, making it more liquid-like compared with a $30 \%$ reduction after gelsolin treatment which severs actin filaments. It suggests that the viscoelasticity of CF sputum is mainly due to the matrix of glycoproteins and not the F-actin and DNA.

The validity of the sputum cell counts in CF was confirmed by comparing them with those in AS/COPD and IB/B. The observed intense neutrophilic inflammatory response in both $\mathrm{CF}$ and $\mathrm{IB} / \mathrm{B}$ was expected given the presence of bacterial infections in both disease groups. Sputum examination was able to differentiate subjects with CF from AS/COPD. Subjects with CF had significantly higher total and neutrophil cell counts while subjects with AS/COPD had a higher percentage of eosinophils.

Different sputum samples obtained from the same subject over $1 \mathrm{~h}$ demonstrated reproducible cell counts. These results should not be compared with the total and differential cell counts from sequential aliquots of hypertonic saline-induced sputum samples. Such studies have shown a small but statistically significant differential pattern of airway inflammation, with the early samples having a higher percentage of neutrophils reflecting a central airway inflammation while later samples have a higher percentage of macrophages indicative of peripheral airway and alveolar inflammation $(12,14)$. In the present study, the four spontaneously expectorated sputum samples were obtained every $15 \mathrm{~min}$ and therefore were most likely to be from central, rather than peripheral, airways.

We decided to use only spontaneously expectorated sputum to validate our sputum processing technique to maximize patient comfort and commitment to the study. We did not expect the 
results to differ from induced sputum because differences have not been previously observed between spontaneous and pooled induced CF sputum samples $(15,16)$ and between spontaneous and induced sputum in asthma and in $\operatorname{COPD}(9,17)$.

Over recent years, anti-inflammatory agents such as corticosteroids and nonsteroidal agents, especially ibuprofen, have been considered as therapeutic agents in CF. Given the potency of these medications and their potential side effects, it would be beneficial to have a means of measuring and monitoring airway inflammation to detect which subjects may or may not benefit from therapy (18). Hence, apart from sputum measurements being useful to study inflammation and the response to treatment, they could be used to predict which subjects will benefit from steroid therapy, similar to AS/COPD, where eosinophilia is a predictor of steroid responsiveness (19-22).

We conclude that the selection method of evaluating cell counts in CF sputum provides an efficient as well as a reproducible and valid measurement of airway inflammation when the sputum weight does not exceed $200 \mathrm{mg}$.

ACKNOWLEDGEMENTS: We thank the subjects in this study, $S$ Carruthers and S Weston for performing the sputum cell counts and P Hussack and R Hennessey for recruiting subjects and performing the clinical measurements.

FUNDING: L Jayaram was supported by Boehringer Ingelheim (Canada) Inc. R Labiris is supported by a career award from Father Sean O'Sullivan Research Centre, St Joseph's Healthcare, Hamilton, Ontario; FE Hargreave was supported by the Father Sean O'Sullivan Research Centre, St Joseph's Healthcare, Hamilton, Ontario.

\section{REFERENCES}

1. Jayaram L, Parameswaran K, Sears MR, Hargreave FE. Induced sputum cell counts: Their usefulness in clinical practice. Eur Respir J 2000;16:150-8.

2. Green RH, Brightling CE, McKenna S et al. Asthma exacerbations and sputum eosinophil counts: A randomised controlled trial. Lancet 2002;360:1715-21.

3. Efthimiadis A, Spanevello A, Hamid Q, et al. Methods of sputum processing for cell counts, immunocytochemistry and in situ hybridisation. Eur Respir J 2002;20(Suppl 37):19s-23s.

4. Picot R, Das I, Reid L. Pus deoxyribonucleic acid and sputum viscosity. Thorax.1978;33:235-42.

5. Rogers DF, Barnes PF. Treatment of airway mucus hypersecretion. Ann Med 2006;38:116-25.
6. Cai Y, Carty K, Gibson P, et al. Comparison of sputum processing techniques in cystic fibrosis. Pediatr Pulmonol 1996;22:402-7.

7. American Thoracic Society. Standardization of spirometry. 1994 Update. Am Rev Respir Dis 1995; 152:1107-36.

8. Crapo RO, Morris AH, Gardner RM. Reference spirometric values using techniques and equipment that meets ATS recommendation. Am Rev Respir Dis 1981;123:659-94.

9. Pizzichini MMM, Popov T, Efthimiadis A, et al. Spontaneous and induced sputum to measure indices of airway inflammation in asthma. Am J Respir Crit Care Med 1996;154:866-9.

10. Efthimiadis A, Popov T, Kolendowicz R, et al. Increasing the yield of sputum cells for examination. Am J Respir Crit Care Med 1994;149:A949. (Abst)

11. Popov T, Gottschalk R, Kolendowicz R, et al. The evaluation of a cell dispersion method of sputum examination. Clin Exp Allergy 1994; 24:778-83.

12. Reinhardt N, Chen CIU, Loppow D, et al. Cellular profiles of induced sputum in children with stable cystic fibrosis: Comparison with BAL. Eur Respir J 2003;22:497-502.

13. Nielsen H, Hvidt S, Sheils CA, Janmey PA. Elastic contributions dominate the viscoelastic properties of sputum from cystic fibrosis patient. Biophys Chem 2004;112:193-200.

14. Aitken ML, Greene KE, Tonelli TR, et al. Analysis of sequential aliquots of hypertonic saline solution-induced sputum from clinically stable patients with cystic fibrosis. Chest 2003;123:792-9.

15. Henig NR, Tonelli MR, Pier MV, et al. Sputum induction as a research tool for sampling the airways of subjects with cystic fibrosis. Thorax 2001;56:306-11.

16. Sagel SD, Kapsner R, Osberg I, Sontag MK, Accurso FJ. Airway inflammation in children with cystic fibrosis and healthy children assessed by sputum induction. Am J Respir Crit Care Med 2001;164:1425-31.

17. Bhowmik A, Seemungal TA, Sapsford RJ, et al. Comparison of spontaneous and induced sputum for investigation of airway inflammation in chronic obstructive pulmonary disease. Thorax 1998;53:953-6.

18. Ramsey BW, Boat TF, for the Consensus Group. Outcome measures for clinical trials in cystic fibrosis: Summary of a Cystic Fibrosis Foundation Consensus Conference. J Pediatr 1994;124:177-92.

19. Pizzichini E, Pizzichini MM, Gibson P, et al. Sputum eosinophilia predicts benefit from prednisone in smokers with chronic obstructive bronchitis. Am J Respir Crit Care Med 1998;158:1511-7.

20. Pavord ID, Brightling CE, Woltmann G, et al. Non-eosinophilic corticosteroid unresponsive asthma. Lancet 1999;353:2213-4.

21. Brightling CE, Monteiro W, Ward R, et al. Sputum eosinophilia and short-term response to prednisolone in chronic obstructive pulmonary disease: A randomised controlled trial. Lancet 2000;356:1480-5.

22. Leigh R, Pizzichini MM, Morris M, Maltais F, Hargreave FE, Pizzichini E. Stable COPD: Predicting benefit from high dose inhaled corticosteroid treatment. Eur Respir J, 2006;27:964-71. 


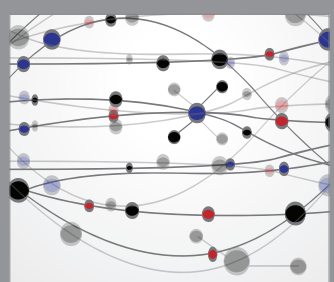

The Scientific World Journal
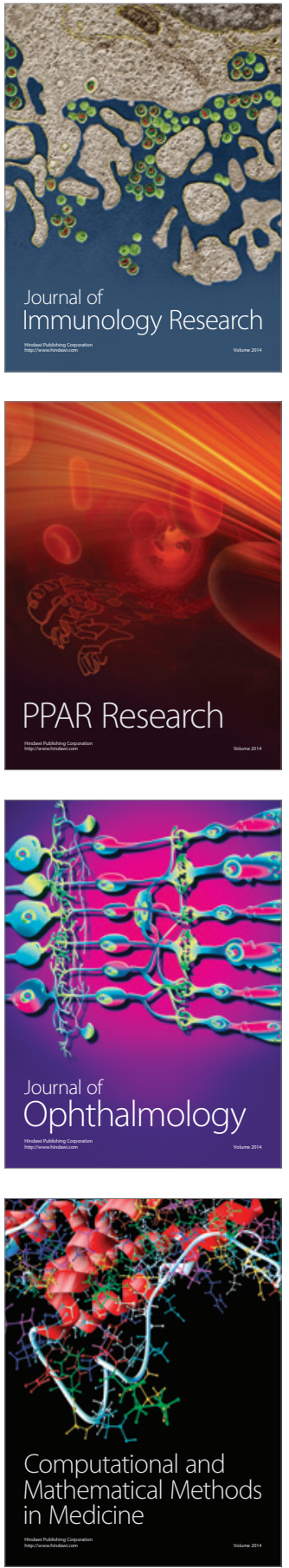

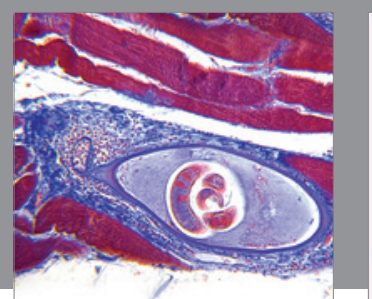

Gastroenterology Research and Practice

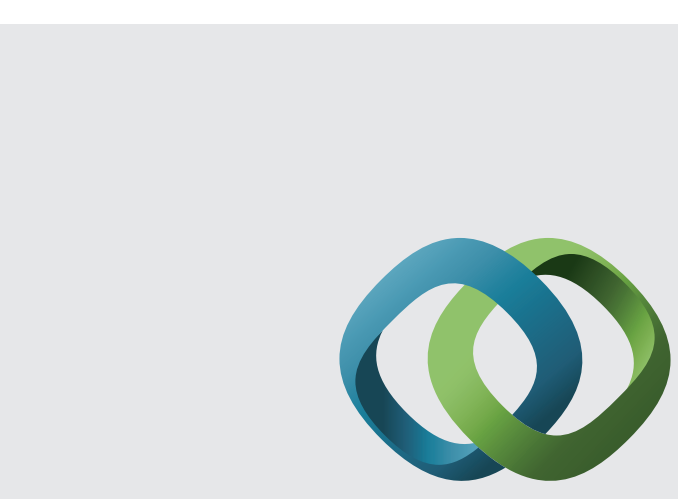

\section{Hindawi}

Submit your manuscripts at

http://www.hindawi.com
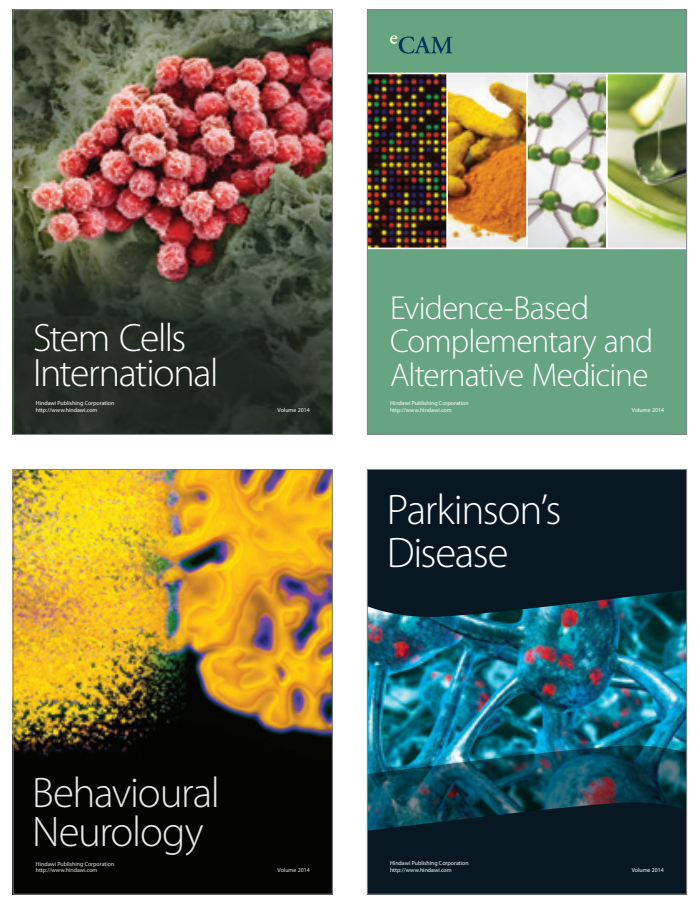
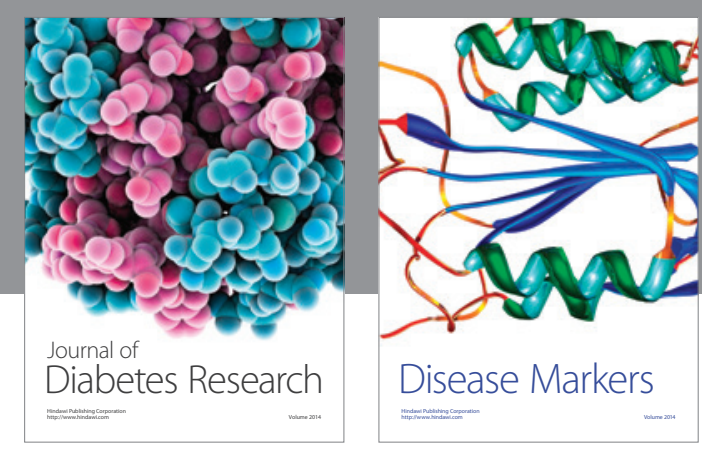

Disease Markers
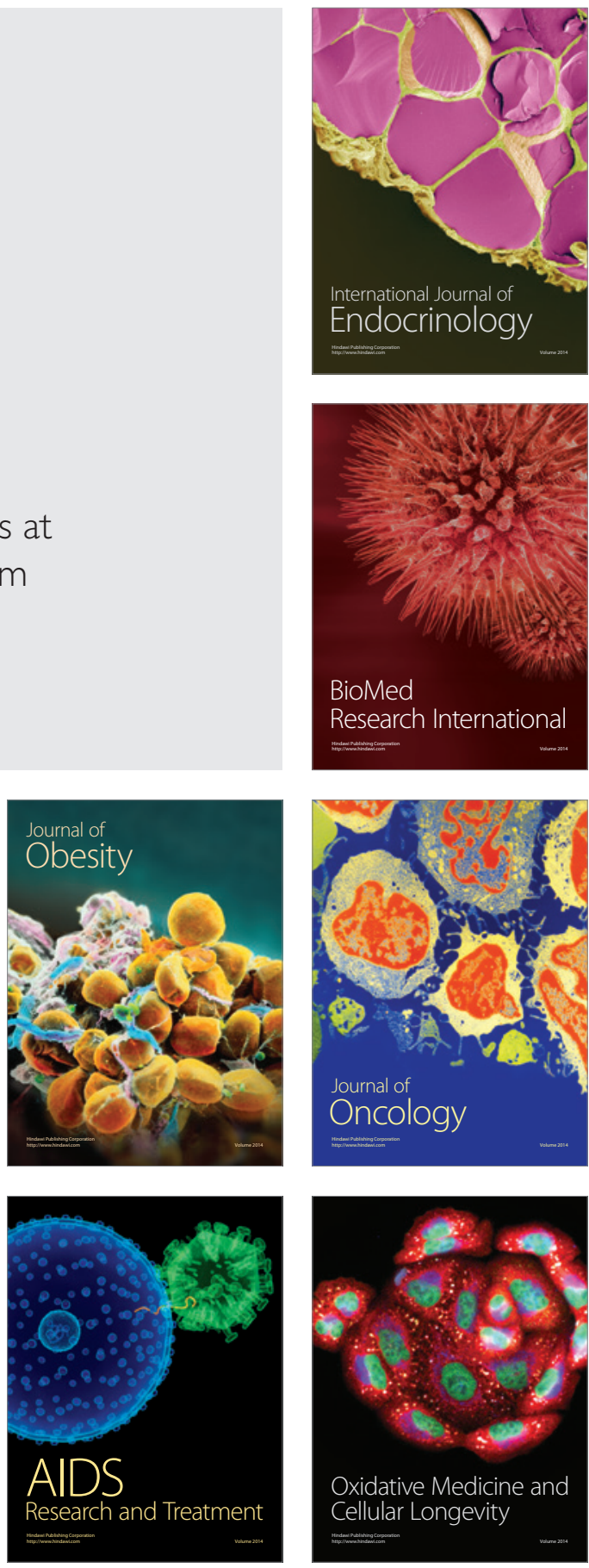